\title{
Gentes peixes e aves
}

\section{People fishes and birds}

Sinopse: O vídeo em questão resulta de uma Oficina de Vídeo Etnográfico realizada pelos integrantes do Grupo de Pesquisa Antropologia das Paisagens: memórias e imaginários na Amazônia, cuja intenção era a de captar imagens e, a partir daí produzir uma narrativa etnográfica por imagens, a fim de refletirmos sobre as interações entre humanos e não-humanos no contexto da Pedra do Peixe, situada no Ver-o-Peso, na cidade de Belém (PA). O vídeo é parte da pesquisa no âmbito da Antropologia Urbana, realizada pelo Dr. Flávio Silveira, figurando como um dos resultados de uma pesquisa em andamento ligada à bolsa de produtividade, financiada pelo CNPq. Para a captação das imagens foram utilizadas Câmeras Canon $5 \mathrm{~d}$ e $60 \mathrm{~d}$.

Synopsis: The video results from an Ethnographic Video Workshop conducted by the members of the Anthropology of Landscapes Research Group: memories and imaginaries in the Amazon, whose intention was to capture images and, from there, produce an ethnographic narrative by images, To reflect on human-non-human interactions in the context of Pedra do Peixe, located in Ver-o-Peso, in the city of Belém (PA). The video is part of Urban Anthropology research, carried out by Dr. Flávio Silveira, as one of the results of an ongoing research linked to the productivity grant, funded by CNPq. Canon $5 d$ and $60 d$ cameras were used to capture the images.

Palavras chave: Cidade. Pedra do Peixe. Interações humano-não-humanos. Socialidades.

Keywords: City. "Pedra do Peixe". Human-non-human interactions. Socialities.

\section{Ficha técnica:}

Produção:

Imagens/Operador de Câmera: Marcelo Rodrigues, Pedro da Rocha Paim, Terezinha de Fátima Ribeiro Bassalo

Edição

Roteirista/Texto: Lanna Beatriz Lima Peixoto, Véronique Isabelle

Credits:

Production:

Images/Cameraperson: : Marcelo Rodrigues, Pedro da Rocha Paim, Terezinha de Fátima Ribeiro Bassalo

Edition

Scriptwriter/Text: Lanna Beatriz Lima Peixoto, Véronique Isabelle 